\title{
Persepsi Masyarakat dan Potensi Public Acceptance Terkait Wacana Pembangunan PLTN di Kabupaten Bengkayang
}

\author{
Netty Herawati ${ }^{\star 1}$, Adityo Darmawan Sudagung ${ }^{2}$ \\ ${ }^{1}$ Program Studi Ilmu Komunikasi, Universitas Tanjungpura, Jl. Prof. Dr. H. Hadari Nawawi, Pontianak Tenggara, Indonesia \\ 2 Program Studi Hubungan Internasional, Universitas Tanjungpura, Jl. Prof. Dr. H. Hadari Nawawi, Pontianak Tenggara, \\ Indonesia
}

\section{INFORMASI ARTIKEL \\ Riwayat Artikel: \\ Diterima: \\ 26 November 2020 \\ Diterima dalam bentuk revisi: \\ 06 Desember 2020 \\ Disetujui: \\ 07 Desember 2020}

Kata kunci:

Persepsi

Energi

Penerimaan Publik

\begin{abstract}
ABSTRAK
PERSEPSI MASYARAKAT DAN POTENSI PUBLIC ACCEPTANCE TERKAIT WACANA PEMBANGUNAN PLTN DI KABUPATEN BENGKAYANG. Pembangkit Listrik Tenaga Nuklir (PLTN) merupakan salah satu jenis pembangkit yang memiliki kelebihan dalam menghasilkan kapasitas listrik yang besar, stabil dan murah. Kelebihan tersebut menjadikan PLTN sebagai salah satu pilihan untuk memenuhi tuntutan ketersediaan listrik yang besar agar dapat menunjang perekonomian berbasis industri di Indonesia. Kabupaten Bengkayang merupakan salah satu daerah yang memiliki potensi untuk dijadikan lokasi tapak PLTN di Kalimantan Barat. Berkaitan dengan pemikiran tersebut, maka perlu dilakukan kajian untuk mengetahui bagaimana persepsi masyarakat serta potensi "public acceptance" sehubungan dengan adanya wacana untuk membangun PLTN di Kalimantan Barat. Tujuan penelitian ini adalah pemaparan kualitatif mengenai persepsi masyarakat di Kabupaten Bengkayang. Metode pengumpulan data dilakukan melalui teknik observasi, wawancara mendalam serta studi literatur. Hasil penelitian menunjukkan bahwa pengetahuan masyarakat Bengkayang tentang nuklir dan PLTN masih sangat terbatas. Hal ini ditunjukkan oleh minimnya wawasan dan pemahaman masyarakat tentang nuklir hampir di semua lapisan. Persepsi masyarakat tentang nuklir pun keliru dengan mengidentikkan nuklir dengan bom dan selalu mengkaitkan PLTN dengan bahaya radiasi dan kecelakaan nuklir. Selain itu, ada kecenderungan masyarakat untuk setuju dan menerima rencana pemerintah untuk membangun PLTN dengan catatan pemerintah dapat menjamin keamanan dan masyarakat mendapat keuntungan dan mafaat yang jelas sebagai dampak kehadiran PLTN di wilayahnya. Kesimpulan dari penelitian ini adalah sikap penerimaan masyarakat tidak sepenuhnya dibangun dari aspek pemahaman publik, namun lebih ditentukan faktor kepentingan dan harapan masyarakat untuk memperbaiki kesejahteraannya.
\end{abstract}

\begin{abstract}
PUBLIC PERCEPTION AND POTENTIAL PUBLIC ACCEPTANCE RELATED TO PLTN DEVELOPMENT PLAN IN BENGKAYANG DISTRICT. Nuclear Power Plant (NPP) is a type of power plant that has the advantage of producing large, stable, and cheap electricity capacity. These advantages make nuclear power plants an option to meet great electricity availability demands to support an industrial-based economy in Indonesia. Bengkayang Regency is an area that can be used as a nuclear power plant site location in West Kalimantan. In connection with this thought, it is necessary to conduct a study to determine how the community's perceptions and the potential for "public acceptance" connect with the discourse to build a nuclear power plant in West Kalimantan. This research aims to describe qualitative research results through observation techniques, interviews, and literature studies as a data collection process. This paper's findings indicated that the Bengkayang community's knowledge of nuclear and nuclear power plants is minimal. This is shown by the lack of public insight and understanding about nuclear at almost all levels. Public perception about nuclear was missing by identifying nuclear bombs and always associating nuclear power plants with radiation hazards and nuclear accidents. Other findings from this paper explained the community's tendency to agree and accept the government's plan to build a nuclear power plant provided that the government can guarantee security. The community will get clear benefits and benefits due to the presence of the PLTN in their area. This research concluded that public acceptance is not fully built from public understanding but rather determines the factors of society's interests and expectations to improve their welfare. Keywords: Perception, Energy, NPP, Public acceptance.
\end{abstract}

\section{PENDAHULUAN}

Provinsi Kalimantan Barat merupakan salah satu provinsi di Indonesia yang kebutuhkan listriknya belum dapat terpenuhi. Terdapat kurang lebih enam ratus desa sampai

${ }^{*}$ Penulis korespondensi.

E-mail: nety.herawaty@fisip.untan.ac.id saat ini masih belum teraliri listrik. Untuk memenuhi kebutuhan listrik masyarakat yang sebagian besar hanya untuk memenuhi kebutuhan skala rumah tangga. Saat ini 67\% 
produksi listrik dipenuhi melalui impor listrik dari Serawak-Malaysia melalui sistem Katulistiwa [1].

Kondisi seperti ini selayaknya tidak dibiarkan dan perlu dicarikan solusi yang tepat. Sebagaimana diketahui Kalimantan Barat adalah pulau yang memiliki begitu banyak sumber daya alam yang apabila dikelola secara maksimal melalui pengembangkan sektor industri tambang, pangan, pariwisata dan lainlain tentunya dapat memberikan kontribusi bagi perekonomian masyarakatnya yang sampai saat ini berada pada tingkat kesejahteraan yang tidak menguntungkan. Selama lima tahun terakhir tingkat kemiskinan di Kalimantan Barat selalu berada diantara 7 hingga 8 persen [2]. Sementara itu berdasarkan data Badan Pusat Statistik (BPS), total jumlah penduduk miskin Indonesia mencapai 25,14 Juta orang (9,41 persen) pada Maret 2019 [3]. Tingginya tingkat kemiskinan di Indonesia dipengaruhi berbagai faktor yang berkaitan dengan kurang berkembangnya sektor industri yang diakibatkan terbatasnya pasokan energi.

Berdasarkan hasil kajian yang dilakukan pemerintah, kabupaten Bengkayang merupakan salah satu daerah yang memiliki potensi untuk dijadikan lokasi tapak PLTN Pada tahun 2018, kabupaten Bengkayang memiliki luas 5.396,30 km2 dengan jumlah penduduk 251.320 jiwa dengan mayoritas penduduknya adalah suku Dayak [4]. Kabupaten Bengkayang sebelumnya merupakan pemekaran dari Kabupaten Sambas dan terletak berbatasan dengan Sarawak, Malaysia dan berada di bagian utara Kalimantan Barat [4].

Dalam rangka mendukung program industrialisasi di Provinsi Kalimantan Barat, Badan Perencanaan Pembangunan Daerah Kalimantan Barat memperkirakan proyeksi kebutuhan listriknya mencapai 3783 MWe sampai tahun 2027[5]. Kebutuhan listrik sebesar itu dibutuhkan untuk industri alumina, rumah tangga, fasilitas umum serta pariwisata. Untuk itu diperlukan strategi arah dan kebijakan dalam memutuskan pembangunan pembangkit listrik yang stabil, ramah lingkungan, murah, aman serta berlimpah. Berdasarkan berbagai hasil kajian, yang memenuhi kriteria tersebut adalah Pembangkit Listrik Tenaga Nuklir. Bisa ditegaskan bahwa kepentingan Pemprov Kalbar atas pembangunan PLTN dikarenakan adanya ketergantungan pada impor listrik dari Malaysia, kebutuhan energi guna menunjang industri dan kesejahteraan masyarakat serta mempertimbangkan hasil kajian BATAN tentang tapak PLTN serta adanya kandungan uranium Kalan.

Terkait aspek regulasi, pemerintah telah menyusun rencana pemanfaatan teknologi nuklir untuk pembangkit tenaga listrik melalui UU No.10/1997 tentang ketenaganukliran serta Peraturan Pemerintah No.2/2014 tentang perijinan reaktor nuklir. Dan instansi yang paling bertanggungjawab terhadap perijinan pembangunan PLTN di Indonesia adalah Badan Pengawas Tenaga Nuklir (Bapeten). Hal ini menunjukkan bahwa pemerintah sudah menunjukkan keseriusan terkait pembangunan PLTN di Indonesia.

Tenaga listrik merupakan sumber energi yang sangat penting bagi kehidupan manusia baik untuk kegiatan industri, kegiatan komersial maupun dalam kehidupan sehari-hari rumah tangga. Semakin bertambahnya jumlah penduduk dan kemajuan di segala bidang kehidupan, maka kebutuhan listrikpun semakin bertambah.

Berkaitan dengan adanya rencana pemerintah untuk membangun PLTN sebagaimana yang tuangkan dalam UU no 17/2007 tentang Rencana Pembangunan Jangka Panjang Nasional, maka Kalimantan Barat termasuk wilayah yang dianggap potensial untuk dibangun PLTN. Apalagi jika dikaitkan dengan deklarasi pada tanggal 26 Agustus 2019 dimana presiden Joko Widodo mengumumkan rencana pemindahan ibu kota baru di wilayah administratif Kabupaten Penajam Paser Utama, Kalimantan Timur, menjadikan Kalimantan Barat berpeluang untuk mensuplai listrik untuk pembangunan dan operasional ibu kota baru.

Sebelumnya di berbagai tempat yang pernah direncanakan untuk dibangun PLTN muncul beberapa aksi yang dilakukan oleh berbagai pihak seperti mahasiswa, LSM, tokoh masyarakat maupun anggota DPR yang menunjukkan penolakan terhadap rencana pemerintah untuk pembangunan PLTN. Melihat alasan-alasan yang dikemukakan tampak adanya kekhawatiran yang berlebihan dari sebagian mereka yang kurang memiliki pengetahuan dan pemahaman yang utuh tentang teknologi nuklir. Sebagaimana yang terjadi dengan rencana pembangunan PLTN Muria 
yang terhambat dikarenakan adanya penolakan keras dari masyarakat [6]. Demikian juga dengan rencana pembangunan PLTN di Bangka Belitung yang juga memperlihatkan pihak yang mendukung itu lebih sedikit jumlahnya dibandingkan mereka yang menolak [7]. Dalam perkembangannya, semakin banyak daerah yang berkeinginan untuk membangun PLTN seperti di Kalimantan Timur dan juga Kalimantan Barat serta Nusa Tenggara Barat dan Bangka Belitung.

Survei BATAN yang dilakukan melalui lembaga riset independen menunjukkan secara nasional tingkat penerimaan masyarakat memperlihatkan kenaikan yang signifikan dari waktu ke waktu. Awalnya pada tahun 2011 dukungan masyarakat baru mencapai 50 persen dan setiap tahun menunjukkan peningkatan dimana sejak tahun 2014 terus menunjukkan peningkatan dan di tahun 2016 tingkat penerimaan masyarakat mencapai 75 persen [8]. Hal menarik dari data jejak pendapat tersebut adalah tingkat penerimaan masyarakat Kalbar sejak 2011 sampai 2016 justru memperlihatkan angka tertinggi yang mencapai hampir 90 persen [8]. Berdasarkan hasil survei tersebut diperoleh informasi mengenai potensi penerimaan publik yang sangat tinggi. Sementara diketahui bahwa sosialisasi PLTN belum dilakukan secara masif apalagi menjangkau seluruh lapisan masyarakat luas di Kalimantan Barat. Karena itu pertanyaan yang dimunculkan dalam kajian ini adalah bagaimana persepsi masyarakat tentang nuklir dikaitkan dengan potensi penerimaan masyarakat yang tinggi di Kabupaten Bengkayang.

Terdapat beberapa penelitian terdahulu yang menjelaskan pola formulasi public attitude terkait PLTN ini, diantaranya yang dikemukakan T.Ohnishi (1995) dan Y.S.Choi et,al (1999) yang mencoba memformulasikan public attitude terkait rencana pembangunan PLTN masing-masing Negara yaitu di Jepang dan Korea [9]. T. Ohnishi (1995) seperti disebutkan dalam Hudaya (2009) menekankan bahwa penentuan keputusan oleh masyarakat didasarkan pada keseimbangan antara informasi positif dan negatif [9]. Hudaya (2009) juga menjelaskan tentang analisis kualitatif yang dilakukan Y.S. Choi et al dalam memformulasikan persepsi publik tentang PLTN di Korea [9]. Metode latent class analisis dan logistic regression digunakan untuk memetakan persepsi publik dan disimpulkan bahwa bahwa dengan meningkatnya informasi maka terdapat kecenderungan positif yang tinggi terhadap PLTN [9].

Berdasarkan pandangan kedua penelitian tersebut, salah satunya menekankan pada pentingnya menyampaikan informasi yang seimbang, artinya menyampaikan informasi secara jujur kepada masyarakat mencakup informasi yang bersifat positif dan juga informasi yang bersifat negatif. Sedangkan yang kedua menekankan bahwa mengubah persepsi masyarakat terhadap PLTN dapat dilakukan dengan menyampaikan informasi sebanyak-banyaknya Artinya, dalam melihat aspek penerimaan masyarakat senantiasa dikaitkan dengan upaya penyampaian informasi untuk membangun atau merubah persepsi negatif masyarakat tentang nuklir. Sehingga dapat dibangun asumsi bahwa penyampaian informasi atau sosialisasi PLTN yang ditujukan untuk memberikan pemahaman masyarakat (public understanding) dan membangun persepsi positif masyarakat merupakan faktor dominan dalam menentukan sikap penerimaan publik (public acceptance). Tujuan penelitian adalah analisis deskriptif kualitatif mengenai persepsi masyarakat dan potensi penerimaan publik terhadap PLTN di Kabupaten Bengkayang.

\section{PERSEPSI MASYARAKAT}

Menurut pendapat Robbins (2001) dalam Merfazi (2019) persepsi masyarakat adalah suatu proses di mana sekelompok manusia yang hidup dan tinggal bersama dalam wilayah tertentu dan memberikan pemahaman terkait peristiwa yang terjadi di lingkungannya [10]. Pendapat lain disebutkan oleh Ani, Roslan, dan Sarpin (2019) bahwa persepsi sosial sering diartikan sebagai proses mempersepsi objekobjek dan peristiwa sosial individu untuk mencoba memahami apa yang tampak dan tidak tampak pada alat indera [11]. Persepsi juga dapat diartikan sebagai pemberian makna pada stimulasi indrawi atau dengan kata lain menanggapi langsung atas sesuatu hal atau peristiwa [11].

Terdapat berbagai faktor yang mempengaruhi sikap penerimaan masyarakat, salah satunya adalah faktor persepsi 
masyarakat. Beberapa hasil kajian mengenai aspek penerimaan masyarakat senantiasa dikaitkan dengan persepsi masyarakat. Semakin positif persepsi masyarakat akan semakin besar dukungan public acceptance. Sedangkan faktor yang dapat mempengaruhi persepi menurut David Krech dan Richard S. Krutch adalah faktor fungsional dan faktor struktural [12]. Faktor fungsional membahas terkait hal-hal yang bersifat pribadi, seperti pengalaman masa lalu, kebutuhan, proses belajar, pengetahuan, cakrawala, latar belakang budaya, nilai kepribadian, dan tingkat pendidikan. Faktor struktural berkebalikan dengan faktor fungsional karena berasal dari luar masing-masing individu. Yaitu, terdiri dari kondisi lingkungan dan stimulus. Persepsi yang terbentuk akan membentuk sikap dan perilaku. Triyaningsih (2020) menjelaskan bahwa pada konteks kehidupan bermasyarakat, persepsi awal terhadap sesuatu sudah dimiliki oleh sekelompok masyarakat tetapi memang dapat berganti sejalan dengan faktor fungsional, mulai dari paparan pemberitaan media, lingkungan, dan stimulus dari tokoh/orang lain [12].

Selain beberapa faktor tersebut, persepsi masyarakat juga dipengaruhi oleh faktor ekonomi. Hasil penelitian dari H, dkk (2019) menunjukkan bahwa dua masalah utama dalam penerimaan masyarakat atas nuklir di Thailand dan Vietnam adalah faktor ekonomi dan edukasi dari pemerintah [13]. Keterkaitan lainnya dari persepsi dan penerimaan dapat ditinjau dari penelitian Wang, dkk (2019) yang menyebutkan bahwa pengetahuan publik berkorelasi positif dengan persepsi manfaat dan penerimaan publik tetapi kadang kala tidak signifikan dengan persepsi risiko [14]. Mereka sebelumnya meneliti persepsi dan penerimaan masyarakat atas energi nuklir di Tiongkok.

Pada konteks kasus pembangunan PLTN di Kabupaten Bengkayang, persepsi masyarakat sebagai sebuah pengetahuan, pemahaman dan sikap penilaian masyarakat diwujudkan dalam sikap penerimaan masyarakat. Pada umumnya persepsi masyarakat terkait nuklir masih diwarnai pandangan dan pemahaman yang keliru. Bagi sebagian besar masyarakat nuklir selalu dikaitkan dengan bom, radiasi, senjata nuklir dan hal-hal yang berkonotasi negatif. Padahal perkembangan teknologi nuklir di berbagai bidang jelas memberikan manfaat yang besar, seperti pertanian, kesehatan, dan teknologi pengawetan makanan dan lain-lain, masih belum banyak diketahui. Sehingga tulisan ini akan menggambarkan persepsi masyarakat sekaligus prediksi tentang potensi penerimaan masyarakat di Kabupaten Bengkayang.

\section{METODOLOGI}

Tulisan ini membahas penelitian dengan menggunakan pendekatan kualitatif [2]. Prosedur penelitian ini menghasilkan data deskriptif. Data primer diperoleh dari informan yang menjadi sumber data kami. Sedangkan data sekunder diperoleh dari berbagai lembaga mitra, serta berbagai referensi yang bertujuan menghasilkan model sosialisasi PLTN untuk membangun penerimaan masyarakat. Teknik pengumpulan data dillakukan melalui wawancara mendalam, observasi, dan dokumentasi. Tiga puluh empat informan dalam penelitian ini adalah seluruh elemen. Informan yang berasal dari lembaga formal terdiri dari Pejabat pelaksana tugas Bupati, Kepala Badan Perencanaan Pembangunan Daerah (BAPPEDA), Sekretaris Daerah, Ketua dan para wakil ketua Dewan Perwakilan Rakyat Daerah (DPRD). Kepala Dinas Koperasi serta beberapa ASN (Aparatur Sipil Negara) di lingkungan Pemerintah Kabupaten Bengkayang. Sementara informan dari kalangan masyarakat umum terdiri dari beberapa ibu rumah tangga, guru, petani, mahasiswa, pelajar dan pedagang. Sedangkan dari organisasi non formal, informasi Penelitian ini diperoleh dari Ketua Majelis Umat Islam (MUI) Kabupaten Bengkayang, Ketua Dewan Adat Dayak, Para Pengurus KNPI serta Ketua Lembaga Pemuda Dayak.

\section{HASIL DAN PEMBAHASAN}

Mengacu pada hasil-hasil riset terdahulu, diperoleh penjelasan yang sebagian besar mengasumsikan bahwa penolakan masyarakat atas pembangunan PLTN disebabkan oleh ketidaktahuan dan kurangnya pemahaman masyarakat tentang nuklir. Hal ini berdampak pada kemunculan persepsi negatif sehingga mengakibatkan public acceptance rendah. Contohnya terjadi di Bangka Belitung dan Muria 
[5,6]. Kondisi ini ternyata tidak berlaku pada masyarakat Kabupaten Bengkayang. Hasil penelitian kami, melalui beberapa kegiatan wawancara kepada berbagai lapisan masyarakat menemukan bahwa terdapat dua kondisi yang bertolak belakang. Kami menemukan bahwa pengetahuan masyarakat atas nuklir memang terbatas, tetapi hal ini tidak menjadikan mereka menolak nuklir. Salah satu alasan terkuat masyarakat yang pengetahunan minim tapi cenderung akan menerima karena disebabkan oleh faktor ekonomi. Lebih tepatnya adanya harapan untuk mendapatkan perubahan dan peningkatan kesejahteraan merupakan alasan kuat masyarakat awam meyetujui PLTN. Artinya masyarakat di Kabupaten Bengkayang lebih mengedepankan faktor stimulus (rencana peningkatan kondisi ekonomi di masa depan) dan pengalaman mereka dengan kondisi ekonomi dan infrastruktur terbatas.

Temuan kami membenarkan bahwa pengetahuan masyarakat Kabupaten Bengkayang memang rendah dalam hal isu nuklir. Terbukti dengan beberapa jawaban yang disebutkan, antara lain seputar bom, radiasi, kecelakaan nuklir, dan senjata pemusnah massal. Sementara pengetahuan bahwa selama ini teknologi nuklir sudah diterapkan dan memberikan manfaat di bidang pertanian, kesehatan, pengawetan makanan dan sebagainya, sama sekali tidak diketahui masyarakat. Bahkan kepemilikan Indonesia atas tiga reaktor nuklir dalam skala riset di Jogjakarta, Bandung, dan Serpong juga tidak diketahui oleh masyarakat. Ketidaktahuan ini menyebabkan ada persepsi awal bahwa masyarakat/teknisi asal Indonesia tidak berpengalaman dalam mengopersionalkan reaktor dan secara umum informan meyakini bahwa SDM Indonesia tidak memadai. 94\% informan kami nilai tidak mengetahui perkembangan teknologi nuklir yang sudah demikian maju.

Kami berpendapat kondisi ini terjadi karena memang masyarakat, bahkan pemerintah daerah juga belum mendapat informasi yang utuh. Kebanyakan masyarakat tidak mencari informasi tentang hal tersebut. Sementara itu. media massa lebih banyak menapilkan berita negatif tentang nuklir dibanding berita positif seperti contoh pemanfaatan nuklir untuk kesejahteraan.
Sebagaimana di dunia maya, dengan algoritma mesin pencari, justru akan lebih banyak memunculkan informasi-informasi dengan paling banyak pencarian (viral) dan sangat mungkin juga menyesatkan karena semua sumber informasi akan tersedia (baik pro dan kontra) di mesin pencarian. Sehingga dengan keterbatasan pengetahuan juga akan mempersulit masyarakat menggunakan kata kunci paling relevan dalam mencari informasi di dunia maya.

Aspek lain yang juga berpengaruh pada persepsi masyarakat atas pembangunan PLTN adalah sosialisasi oleh pemerintah. Hal yang membuat persepsi masyarakat bersifat negatif karena rendahnya tingkat kepercayaan kepada pemerintah. Para informan kami dari perwakilan masyarakat mengatakan bahwa ada persoalan kepercayaan mereka terhadap pemerintah. Tingkat kepercayaan masyarakat sangat rendah kepada pemerintah sehubungan pengalaman mereka selama ini, contohnya kasus lahan kelapa sawit. Pemerintah awalnya menyosialisasikan bahwa sawit akan meningkatkan kesejahteraan masyarakat tetapi buktinya sekarang banyak timbul masalah termasuk masalah lingkungan dan kehidupan masyarakat yang semakin miskin. Oleh karena itu, menurut kami apabila pemerintah akan melakukan sosialisasi lagi di waktu yang akan datang, penting untuk mengedepankan kejujuran. Hal ini juga dikemukakan oleh informan kami yang sangat ingin pemerintah jujur menyampaikan apa dampak positif dan negatif dari kehadiran PLTN dan apa manfaat konkrit yang bisa dirasakan masyarakat.

Kondisi ini sejalan dengan penelitian terdahulu yang dilakukan oleh Ho, dkk (2019) yang mengemukakan bahwa masyarakat di Thailand dan Vietnam memiliki ketidakpercayaan yang sama atas pemerintah. Penelitian tersebut bahkan menyimpulkan bahwa masyarakat memiliki persepsi bahwa negara mereka belum siap memiliki PLTN. Salah satunya seperti di Vietnam, masyarakat meyakini bahwa pemerintah belum memiliki kepakaran yang mumpuni dalam mengelola PLTN. Sementara masyarakat Thailand, meski dalam aspek kepakaran sudah terpenuhi tetapi mereka meyakini bahwa masyarakat perlu lebih diedukasi akan pentingnya energi nuklir [13]. Penelitian tersebut juga menemukan bahwa pangkal permasalahan dari persepsi negatif 
sering didominasi oleh kesalahpahaman dan kesimpangsiuran informasi.

Berdasarkan temuan kami di lapangan diperoleh gambaran mengenai persepsi masyarakat atas nuklir yang sifatnya negatif dan pengetahuan yang sangat minim tentang nuklir. Faktor pemberitaan, ketersediaan informasi, sosialisasi, dan pengetahuan masyarakat menjadi penyebab utama. Pada beberapa lokasi studi terdahulu menunjukkan bahwa persepsi awal ini akan sangat berkorelasi dengan penerimaan masyarakat akan rencana pembangunan PLTN. Contohnya di Muria dan Bangka Belitung yang memiliki persepsi negatif berdampak pada penerimaan negatif, atau Korea dan Jepang yang menerapkan strategi sosialisasi yang masif sehingga menumbuhkan persepsi positif dan menyebabkan penerimaan masyarakat cukup tinggi. Tetapi, kondisi ini tidak berlaku pada masyarakat di Bengkayang.

Kendati pun persepsi masyarakat negatif dan tingkat kepercayaan pada pemerintah relatif rendah. Namun pada saat ditanyakan mengenai persetujuan jika daerahnya akan dibangun PLTN, sebagian besar menyatakan setuju dengan berbagai argumentasi. Fenomena konkrit dan kontras di masyarakat Bengkayang ini menunjukkan potensi penerimaan masyarakat yang sangat tinggi. walaupun demikian sikap penerimaan ini memastikan syarat akan adanya manfaat konkrit bagi masyarakat dan juga pendapatan daerah. Mereka meminta khususnya pembangunan PLTN dapat mengangkat perekonomian sehingga mereka bisa mengubah hidupnya menjadi lebih baik dan sejahtera. Sikap penerimaan masyarakat ini sangat berkaitan dengan kehidupan yang belum sejahtera serta pendidikan yang rendah. Tampaknya kondisi tersebut menjadikan mereka mudah menerima gagasan pembangunan yang dianggap bisa memperbaiki kondisi kehidupan masyarakat tanpa sikap kritis.

Kejadian yang sama juga sempat terjadi di Thailand dan Vietnam berdasarkan penelitian Ho, dkk (2019) yang memperlihatkan bahwa masalah ekonomi menjadi salah satu alasan utama masyarakat akan menerima rencana pembangunan PLTN [13]. Sebagai sesama masyarakat negara berkembang, kedua masyarakat memiliki kecenderungan yang sama akan prioritas ekonomi dibandingkan pelestarian lingkungan hidup yang dikhawatirkan. Sehingga harapan untuk kehidupan yang lebih sejahtera dengan energi nuklir menjadi potensi yang sangat besar bagi penerimaan masyarakat atas rencana pembangunan PLTN, khususnya pada lokasi penelitian kami di Kabupaten Bengkayang.

\section{KESIMPULAN}

Potensi penerimaan masyarakat yang cenderung sangat tinggi bukan disebabkan pemahaman masyarakat tentang manfaat dan resiko nuklir secara utuh, sebagaimana dalam tinjauan pustaka disebutkan bahwa persepsi akan berbanding lurus dengan pengetahuan dan kondisi ekonomi. Pada kasus di Kabupaten Bengkayang, meskipun secara pendidikan masyarakatnya tergolong rendah dan bahkan kurang teredukasi terkait teknologi nuklir, namun dibandingkan dengan keinginan untuk mengubah nasib menjadi lebih baik secara ekonomi, membuat mereka mengindikasikan akan menerima pembangunan PLTN. Masyarakat menjelaskan bahwa meskipun secara umum persepsi mereka tentang nuklir negatif, namun demi menginginkan masa depan yang lebih sejahtera mereka bersedia mengalihkan persepsi negatif dan rasa takut tersebut pada pertimbangan yang akan berdampak pada kehidupan yang lebih baik. Harapan masyarakat, pemerintah segera melakukan sosialisasi yang mengutamakan informasi dan edukasi terkai t dampak positif dan negatif dari keberadaan PLTN di daerah Kabupaten Bengkayang.

\section{UCAPAN TERIMA KASIH}

Ucapan terima kasih kami sampaikan kepada Allah SWT yang memberikan ilham dan petunjuk dalam menjalankan aktivitas penelitian. Terima kasih kami ucapkan kepada proyek INSINAS yang telah mendanai kegiatan penelitian yang kami lakukan. Tidak lupa kami ucapkan terima kasih kepada pihak-pihak terkait yang berkenan menjadi informan. Selain itu, ucapan terima kasih diberikan kepada rekan tim penelitian lain yang berbagi tugas dalam penyelesaian pekerjaan ini serta keluarga yang selalu mendukung kami dalam setiap kegiatan. 


\section{DAFTAR ACUAN}

[1]. Candranurani, C. dkk, “Analisis Aliran Daya untuk Penentuan Lokasi Penyaluran Daya PLTN Pada Sistem Kalimantan Barat”, Jurnal Pengembangan Energi Nuklir Vol.17 No. 1 Hal. 67-77, 2015.

[2]. Yacoub, Y. dan Apriani, N., "Determinan Kemiskinan di Provinsi Kalimantan Barat", in Prosiding Akademik Tahunan Ilmu Ekonomi dan Studi Pembangunan, hal. 143-152, 2019.

[3]. BPS, 2019. Provinsi Kalimantan Barat dalam Angka 2019. Badan Pusat Statistik Provinsi Kalimantan Barat, Pontianak.

[4]. BPS, 2019. Kabupaten Bengkayang Dalam Angka 2019. BPS Kabupaten Bengkayang, Bengkayang.

[5]. Dinas ESDM Provinsi Kalimantan Barat. 2020. Rencana Umum Energi Daerah Provinsi Kalimantan Barat. Dinas ESDM Provinsi Kalimantan Barat, Pontianak.

[6]. Hariyadi, "Agenda-Setting Pembangunan PLTN dan Pencapaian Ketahanan Listrik (Studi di Jepara dan Pangkal Pinang), Jurnal Ekonomi \& Kebijakan Publik, Vol. 7, No. 2, Desember, 2016.

[7]. Suhaemi, T., Napis, Sudirman, "Partisipasi Masyarakat dalam Pembangunan Pembangkit Listrik Tenaga Nuklir di Indonesia", in Prosiding Seminar Nasional Pendidikan Sains (SNPS) IV, Surakarta, 2014.

[8]. Badan Tenaga Nuklir Nasional. Desember 2015. "75\% Masyarakat Indonesia Siap Menerima PLTN". Badan Tenaga Nuklir Nasional. [Online]. Available: http://www.batan.go.id/index.php/id/kedeputian/ma najemen/hhk/1971-75-masyarakat-indonesiatelah-siap-menerima-pltn. [Diakses pada 01 Oktober 2020].

[9]. Hudaya. C."Mencari Formula Sosialisasi PLTN yang Tepat". [Online]. Available: https://staff.blog.ui.ac.id/chairul.hudaya/2008/10/2 2/mencari-formula-sosialisasi-pltn-yang-tepat2. [Diakses pada 01 Oktober 2020].

[10]. Merfazi. M, Sugiarto, Dan Anggraini. R, "Persepsi Masyarakat Terhadap Kebijakan Trans Koetaradja Pada Koridor Pusat Kota - Matale dan Pusat Kota - Ajun - Lhoknga Menggunakan Indikator Variabel Laten", Jurnal Arsip Rekayasa Sipil dan Perencanaan, Vol 2(1), 58-67, 2019.

[11]. Ani. P, Suharty Roslan, dan Sarpin, "Perubahan Persepsi Masyarakat Terhadap Keikutsertaan Dalam Program Keluarga Berencana (Studi di Kelurahan Kendari Caddi Kecamatan Kendari Kota Kendari)", Neo Societal, Vol 4 (1), 2019.

[12]. Triyaningsih. H, "Efek Pemberitaan Media Massa Terhadap Persepsi Masyarakat Pamekasan Tentang Virus Corona", Meyarsa Vol 1 (1), 1-21, 2020.

[13]. Shirley S. et.al, "Exploring public perceptions of benefits and risks, trust, and acceptance of nuclear energy in Thailand and Vietnam: A qualitative approach”, Energy Policy, 127, pp.259-268, 2019.

[14]. W. Shanyong, et.al, "Energy in China: The Role Of Public Knowledge, Perceived Benefit, Perceived Risk and Public Engagement”, Energy Policy, 126, pp.352-360, 2019.. 
HALAMAN INI SENGAJA DIKOSONGKAN 